\title{
A case study of the radiative effect of aerosols over Europe: EUCAARI-LONGREX
}

\author{
Anna R. Esteve ${ }^{1,2, a}$, Eleanor J. Highwood ${ }^{2}$, and Claire L. Ryder ${ }^{2}$ \\ ${ }^{1}$ Department of Earth Physics and Thermodynamics, University of Valencia, Valencia, Spain \\ ${ }^{2}$ Department of Meteorology, University of Reading, Reading, UK \\ ${ }^{a}$ now at: Department of Experimental and Social Sciences Teaching, University of Valencia, Valencia, Spain
}

Correspondence to: Anna R. Esteve (anna.esteve@uv.es)

Received: 23 November 2015 - Published in Atmos. Chem. Phys. Discuss.: 15 February 2016

Revised: 11 May 2016 - Accepted: 3 June 2016 - Published: 23 June 2016

\begin{abstract}
The radiative effect of anthropogenic aerosols over Europe during the 2008 European Integrated Project on Aerosol Cloud Climate and Air Quality Interactions Long Range Experiment (EUCAARI-LONGREX) campaign has been calculated using measurements collected by the Facility for Airborne Atmospheric Measurements (FAAM) BAe-146 aircraft and radiative transfer modelling. The aircraft sampled anthropogenically perturbed air masses across northwestern Europe under anticyclonic conditions with aerosol optical depths ranging from 0.047 to 0.357 . For one specially designed "radiative closure" flight, simulated irradiances have been compared to radiation measurements for a case of aged European aerosol in order to explore the validity of model assumptions and the degree of radiative closure that can be attained given the spatial and temporal variability of the observations and their measurement uncertainties. Secondly, the diurnally averaged aerosol radiative effect throughout EUCAARI-LONGREX has been calculated. The surface radiative effect ranged between -3.9 and $-22.8 \mathrm{~W} \mathrm{~m}^{-2}$ (mean $-11 \pm 5 \mathrm{~W} \mathrm{~m}^{-2}$ ), whilst topof-the-atmosphere (TOA) values were between -2.1 and $-12.0 \mathrm{~W} \mathrm{~m}^{-2}$ (mean $-5 \pm 3 \mathrm{~W} \mathrm{~m}^{-2}$ ). We have quantified the uncertainties in our calculations due to the way in which aerosols and other parameters are represented in a radiative transfer model. The largest uncertainty in the aerosol radiative effect at both the surface and the TOA comes from the spectral resolution of the information used in the radiative transfer model ( $\sim 17 \%$ ) and the aerosol description (composition and size distribution) used in the Mie calculations of the aerosol optical properties included in the radiative trans-
\end{abstract}

fer model $(\sim 7 \%)$. The aerosol radiative effect at the TOA is also highly sensitive to the surface albedo $(\sim 12 \%)$.

\section{Introduction}

Atmospheric aerosols play an important role in the Earth's climate through modifications of the global radiation budget, directly through the scattering and absorption of radiation (Charlson et al., 1992; Haywood and Shine, 1997) and indirectly via changes to cloud microphysics and properties (Kaufman et al., 2005). These effects are potentially considerable but uncertain. The global mean direct radiative forcing from 1750 to 2011 due to all anthropogenic aerosol has been estimated as $-0.27 \pm 0.5 \mathrm{~W} \mathrm{~m}^{-2}$, and the indirect effect as -0.55 (with a range from -1.33 to -0.06 ) $\mathrm{W} \mathrm{m}^{-2}$ (IPCC, 2013). This rather large uncertainty in both the direct and indirect forcing is due to the variability of the optical properties and the spatial-temporal distribution of the aerosols, together with the variability of the macrophysical and microphysical properties of clouds in the case of the indirect forcing. In order to reduce these uncertainties, the integration of data from different platforms (ground-based networks, satellite, aircraft, etc.) and techniques (in situ measurement, remote sensing, numerical modelling, and data assimilation) is required (Penner et al., 1994; Heintzenberg et al., 1996; Diner et al., 2004; Yu et al., 2006). For this reason, a great effort has been made in the last decades to establish ground-based networks, develop new satellite sensors, and perform field experiments around the world (Kahn et al., 2004). 
In situ measurements made by ground-based networks or in field experiments provide important aerosol information such as loading, vertical distribution, optical properties, or chemical composition, although they usually are very limited in space and time. Nowadays, satellite measurements allow regional-to-global-scale analyses, while chemical transport models are used to interpolate and provide data in regions where observations are not available. However, in situ measurements are still needed for evaluating both the satellite retrievals and the model simulations. Moreover, climate simulations by numerical models require accurate representation of the physical and chemical properties of aerosols and their processes, and this will be ultimately based on experimental measurements. Thus, the comparison of different measurement platforms and techniques, together with the comparison of dependent aerosol properties and effects, is leading to a better understanding of the properties and processes of atmospheric aerosols as well as their role in radiative transfer. These studies, which are referred to as "closure" studies, have been performed before in a variety of aerosol regimes in field campaigns such as the Tropospheric Aerosol Radiative Forcing Observational Experiment, TARFOX (Russell et al., 1999); the Indian Ocean Experiment, INDOEX (Ramanathan et al., 2001); the Southern African Regional Science Initiative, SAFARI 2000 (King et al., 2003); the Aerosol Characterization Experiment-Asia, ACE-Asia (Huebert et al., 2003); and the Aerosol Direct Radiative Impact Experiment, ADRIEX (Highwood et al., 2007).

The European Integrated Project on Aerosol Cloud Climate and Air Quality Interactions Long Range Experiment (EUCAARI-LONGREX) was an aircraft field campaign conducted over central Europe and off the UK coast in May 2008. This campaign focused on the horizontal and vertical distribution of aerosol and trace gases on a continental scale throughout the tropospheric column. The synoptic and pollution situation during EUCAARI-LONGREX can be found in Hamburger et al. (2011); in summary, an anticyclone over Scandinavia provided easterly flow across northern Europe such that aged European aerosol could be measured over the eastern North Atlantic Ocean. The chemical composition of airborne measurements inside the boundary layer and its impact on the radiative budget over Europe are presented in Morgan et al. (2010a, b). The black carbon measurements have been analysed by McMeeking et al. (2010). The aerosol optical measurements have been discussed by Highwood et al. (2012). The level of agreement between the calculated and measured aerosol optical properties during the campaign has been analysed by Esteve et al. (2014).

In this case study, we have used the data collected by the Facility for Airborne Atmospheric Measurements (FAAM) BAe-146 aircraft during EUCAARI-LONGREX to calculate the radiative effect of aerosols of different ages over Europe. Building on Esteve et al. (2014), we have also quantified the uncertainties in our calculations due to the variability of aerosol properties and the way in which they are repre- sented in models. Section 2 of this paper briefly describes the data and instrumentation from the FAAM BAe-146 aircraft and the radiative transfer model used in our calculations. Section 3 presents a radiative closure study for the only specially designed flight for this purpose within EUCAARILONGREX, a case with predominantly clear skies and high concentrations of aged European aerosol. For this flight alone, radiation and aerosol in situ measurements were possible within, above, and below the aerosol layer, which allows validation of the model radiation calculations. Such radiation measurements were not possible during the rest of the EUCAARI-LONGREX flights due to aircraft operational restrictions, so for these flights the in situ aerosol measurements are used in Sect. 4 to calculate the radiative effect over Europe during the campaign. Section 5 discusses the uncertainties associated with the calculated aerosol radiative effects. The conclusions are presented in Sect. 6 .

\section{Methodology}

\subsection{FAAM BAe-146 aircraft data and instrumentation}

During the EUCAARI-LONGREX campaign, the FAAM BAe-146 aircraft made 15 flights in the region $47-57^{\circ} \mathrm{N}$ and $12^{\circ} \mathrm{W}-22^{\circ} \mathrm{E}$. Flight patterns generally consisted of either north-south transects to cut across air mass gradients or east-west transects to follow the air mass trajectories. Aircraft manoeuvres consisted of straight level runs (SLRs) at different altitudes and vertical profiles through the boundary layer. Table 1 shows the flights and deep vertical profiles made during EUCAARI-LONGREX that have been selected in this paper to calculate the radiative effect of aerosols over Europe during this case study.

The instrumentation aboard the FAAM BAe-146 aircraft measured the chemical composition, microphysical, opti$\mathrm{cal}$, and hygroscopic properties of the atmospheric aerosols, as well as the shortwave solar radiation, and it has been described in detail in Johnson et al. (2000), Haywood et al. (2001, 2003), Osborne et al. (2007), McMeeking et al. (2010), and Morgan et al. (2010a). Only the instrumentation relevant for our study is briefly described here, and it is summarized in Table 2.

The aerosol scattering coefficients at 440,550, and $700 \mathrm{~nm}$ are measured by a TSI 3563 integrating nephelometer. These values are corrected for angular truncation, temperature, and pressure following Anderson and Ogren (1999) and Turnbull (2010). Although the sample is not actively dried during these flights, these measurements are assumed to be applicable to "dry" aerosol. A second TSI 3563 integrating nephelometer ("wet nephelometer") is operated with a humidified relative humidity $(\mathrm{RH})$ between 45 and $95 \%$ in series with the first nephelometer (e.g. Haywood et al., 2008). During a SLR, the humidity is either cycled through a range between these values or set at a fixed high level. Thus, the hygroscopic 
Table 1. Flights and deep vertical profiles selected to calculate the radiative effect of aerosols over Europe during EUCAARI-LONGREX. Deep vertical profiles provide the most complete description of the vertical distribution of the aerosol.

\begin{tabular}{lllrl}
\hline Flight & Profile & Date & Altitude (m) & General location \\
\hline b362 & P9+P10 & 6 May 2008 a.m. & $90-3000$ & Germany/Belgium and N. Sea \\
b365 & P7 & 8 May 2008 a.m. & $60-3100$ & Eastern Europe and Baltic Sea \\
b369 & P6.3 & 10 May 2008 p.m. & $70-2600$ & Baltic Sea and Germany \\
b370 & P1 & 12 May 2008 a.m. & $60-3000$ & Germany, Netherlands, and N. Sea \\
b370 & P4.2 & 12 May 2008 a.m. & $580-3400$ & Germany, Netherlands, and N. Sea \\
b371 & P2.2 & 12 May 2008 p.m. & $40-1900$ & Germany and Baltic Sea \\
b373 & P7 & 13 May 2008 p.m. & $60-3000$ & Southern UK coast \\
b374 & P2 & 14 May 2008 a.m. & $20-3700$ & Atlantic Ocean SW of Ireland \\
b374 & P6 & 14 May 2008 a.m. & $3-6700$ & Atlantic Ocean SW of Ireland \\
b380 & P3.2 & 22 May 2008 a.m. & $640-2300$ & Germany, Netherlands, Belgium, and southern UK coast \\
\hline
\end{tabular}

Table 2. Summary of the aerosol and radiation sampling instrumentation aboard the FAAM BAe-146 during the EUCAARI-LONGREX campaign.

\begin{tabular}{lll}
\hline Instrument & Measurement & Sensitivity \\
\hline $\begin{array}{l}\text { TSI 3563 integrating } \\
\text { nephelometer }\end{array}$ & "Dry" and "wet" aerosol light scattering coefficient & $\sim 20 \%$ (Johnson and Osborne, 2011) \\
PSAP & at 450, 550, 700 nm & \\
PCASP & Dry aerosol absorption coefficient at $567 \mathrm{~nm}$ & $\sim 30 \%$ (Bond et al., 1999) \\
ToF-AMS & Dry aerosol size distribution & $\pm 20 \%$ (diameter), $\pm 15 \%$ (concentration) \\
SP2 & Aerosol composition (non-refractory mass) & $\sim 25 \%$ (Canagaratna et al., 2007) \\
PSP & Refractory black carbon mass & $\sim 30 \%$ (Schwarz et al., 2006) \\
& Downwelling and upwelling irradiance $(0.3-3 \mu \mathrm{m})$ & $\pm 8 \%$ (Haywood et al., 2001, 2003) \\
\hline
\end{tabular}

scattering growth factor, $f(\mathrm{RH})$, can be estimated as the ratio of the scattering coefficient measured in the wet nephelometer to the scattering coefficient measured by the standard nephelometer and plotted as a function of RH to obtain a hygroscopicity curve for each flight of the campaign. To minimize the uncertainty due to the unknown RH of the sample in the "dry nephelometer", only sections of SLRs where the $\mathrm{RH}$ measured in the dry nephelometer is less than $30 \%$ are used. The "measured" scattering for "ambient" aerosol at a given relative humidity is then derived by increasing the scattering from the nephelometer by the growth factor indicated by the hygroscopicity curve. A more detailed description of this process can be found in Highwood et al. (2012).

The aerosol absorption coefficient at $567 \mathrm{~nm}$ is measured by a Radiance Research Particle Soot Absorption Photometer (PSAP). These values are corrected for pressure and flow rate and for spot size effects following Bond et al. (1999), Ogren (2010), and Turnbull (2010). The absorption at $550 \mathrm{~nm}$ is found assuming an inverse dependence of the absorption with the Ångström exponent (e.g. Bond and Bergstrom, 2006). These measurements are also assumed to be representative of dry aerosol and not to change with relative humidity. As such, the derived ambient extinction coefficient is comprised of a humidity growth adjusted scattering and humidity unchanged absorption.
The aerosol size distribution is measured by a wingmounted particle measuring system, the Passive Cavity Aerosol Spectrometer Probe 100-X (PCASP). This provides aerosol sized in 15 bins (previously calibrated in the laboratory) with diameters between 0.1 and $3 \mu \mathrm{m}$ approximately. Considering the dehydrating nature of the PCASP (Strapp et al., 1992), this is taken to be the dry aerosol size distribution. We have taken into consideration the known difference in bin sizing from the calibration latex spheres based on our estimate of the refractive indices of the aerosol as described in Rosenberg et al. (2012). The drift of this offset has been shown to be small over the duration of a campaign.

The aerosol composition is measured by an Aerodyne Time-of-Flight Aerosol Mass Spectrometer (ToF-AMS) for the total non-refractory mass (e.g. organics, nitrate, sulphate, ammonium, and chloride) and by a Single Particle Soot Photometer (SP2) for the mass of sub-micron refractory black carbon.

Measurements of downwelling and upwelling irradiances are made using Eppley Precision Spectral Pyranometers (PSPs) mounted above and below the fuselage. These instruments have a spectral range of $0.3-3 \mu \mathrm{m}$. The accuracy of standard PSPs is $\pm 1 \%$ (Burns et al., 2000), but additional uncertainties encountered when mounted and flown on the aircraft due to pitch and roll corrections result in an overall 
accuracy of the FAAM BAe-146 PSPs of up to $\pm 8 \%$ (Haywood et al., 2001, 2003).

\subsection{Radiative transfer calculations}

Calculations of downwelling and upwelling irradiances are performed using the Edwards and Slingo (ES96) radiative transfer model (Edwards and Slingo, 1996; Randles et al., 2013) with a plane-parallel atmosphere and a spectral resolution of 220 bands in the range $0.2-10 \mu \mathrm{m}$. Vertical profiles of temperature, water vapour, ozone, and aerosol mass mixing ratio are calculated from measurements of the FAAM BAe146 aircraft. At altitudes above the aircraft profiles, the midlatitude climatology of McClatchey et al. (1971) is used for temperature, water vapour, and ozone. When the aircraft was unable to get close enough to the surface (SFC) (since it is difficult to fly at low altitude over European land), these parameters were also extended to the surface, assuming a constant profile from the minimum aircraft altitude. McClatchey et al. (1971) mid-latitude climatology is also used for $\mathrm{CO}_{2}$, $\mathrm{O}_{2}, \mathrm{CH}_{4}$, and $\mathrm{N}_{2} \mathrm{O}$, which the aircraft did not measure. Aerosol optical properties (single-scattering albedo, mass extinction coefficient, and asymmetry parameter) are specified in the simulations by calculating them with a Mie scattering code within a framework that includes the measured composition and dry size distribution for the closest SLRs to each vertical profile and grows the aerosol according to parameterisation of growth factors from the literature (Esteve et al., 2014). Since ES96 is run in two streams, the asymmetry parameter is provided rather than a description of the full scattering phase function. The vertical aerosol profile in terms of mass mixing ratio is provided as an input to ES96. For this, the vertical profile of the aerosol scattering measured by the FAAM BAe-146 aircraft must be converted first to a vertical profile of the extinction coefficient by dividing by the single-scattering albedo measured at an appropriate altitude, and then the extinction coefficient can be converted to a mass mixing ratio using the mass extinction coefficient. For simplicity, a Lambertian surface albedo is assumed. This is obtained either from pyranometer measurements of upwelling and downwelling irradiance during SLRs close to the surface or from the Modern Era Retrospective-analysis for Research and Applications (MERRA) database (Rienecker et al., 2011). Solar zenith angle is specified for each case depending on flight time and location. The solar irradiance at the top of the atmosphere (TOA) is specified based on standard solar geometry.

\section{Radiative closure between model and measurements - case study}

Pyranometer-measured irradiances can be used together with ES96-modelled irradiances in order to validate the results from the model and evaluate the degree of radiative closure
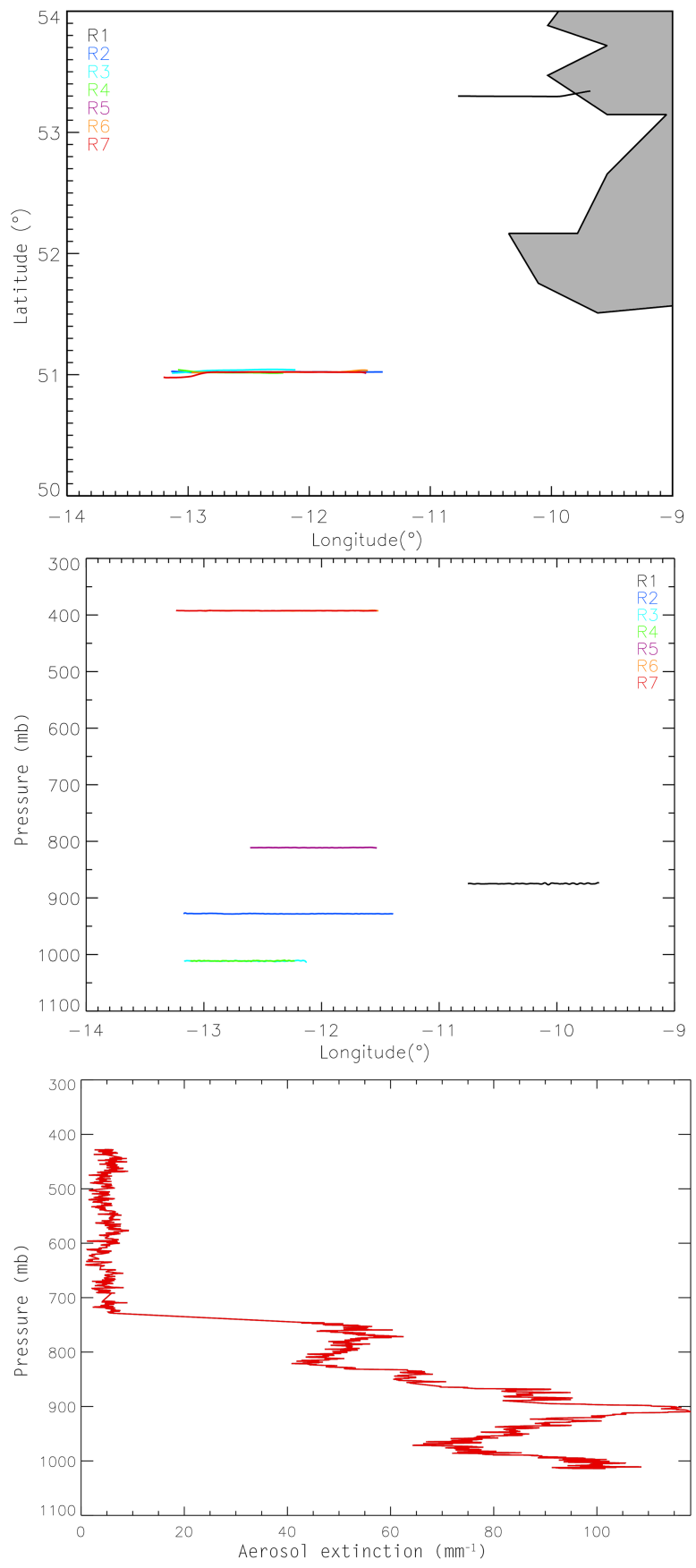

Figure 1. Flight b374 pattern for each SLR as a function of geographic location showing the southwest of Ireland shaded grey (top) and the pressure at which the measurements were made (middle). Vertical profile of aerosol extinction at $550 \mathrm{~nm}$ during flight b374 (bottom).

that can be achieved. However to do this, very specific flight patterns (full profiles to close to ground level, stacked straight and level runs, including close to ground level and above the aerosol layer) and conditions (cloud-free skies, high aerosol 
concentrations) are needed. During EUCAARI-LONGREX, only one such opportunity was available. Flight b374, which was performed on 14 May 2008 off the western coast of Ireland, had a flight pattern designed specifically to do this based on the predominantly clear skies and high concentrations of aged European aerosol. Figure 1 shows the location of the seven SLRs that were performed at different altitudes during flight b374. The SLRs designed specifically for radiative closure purposes include two SLRs within the aerosol layer off the Irish coast (R2 at $\sim 928 \mathrm{mb}$ and R5 at $\sim 811 \mathrm{mb}$ ), two SLRs in opposite headings below the aerosol layer (R3 and R4 at $\sim 1011 \mathrm{mb}$ ), and two SLRs in opposite headings above the aerosol layer (R6 and R7 at $\sim 392 \mathrm{mb}$ ). Vertical profiles through the boundary layer were also performed between SLRs. An additional SLR was performed within the aerosol layer much closer to the Irish coast (R1) while overflying the Mace Head ground sampling site, likely sampled different aerosol, and was not consistent in time or space with the rest of the flight segments. It is therefore not analysed further in this study. The vertical profile of the aerosol extinction calculated from the measured scattering and absorption (from the nephelometer and PSAP) for flight b374 is shown as well in Fig. 1 .

In order to obtain model irradiances comparable to pyranometer measurements, average solar zenith angles for the times of each SLR are used to run ES96, and model results are then selected at pressure levels corresponding to those of the flight SLRs. Pyranometer data are also averaged over SLRs in order to compare to model data. The surface albedo in this case is calculated as the ratio of the upwelling irradiance to the downwelling irradiance measured when the aircraft was flying close to the surface (below $20 \mathrm{~m}$ height), providing a value of $0.033 \pm 0.001$. This value is close to the lower limit of the range found by Jin et al. (2004) for the clear-sky ocean albedo, which varies greatly $(0.03-0.4)$ depending on the solar zenith angle, the aerosol loading, and the wind speed.

Figure 2 shows the comparison of the modelled irradiances to the measured ones for both the shortwave downwelling (SWD) and upwelling (SWU) irradiances (• symbols) through scatter plots (Fig. 2a and b) and in terms of absolute differences (Fig. 2c and d) and percentage differences (Fig. 2e and f) as a function of the pressure at which the pyranometer measurements were made. There is very good agreement between model and pyranometer for both the SWD and SWU irradiances, with the difference between pyranometer and model data being within the pyranometer uncertainty. Good agreement at high altitudes is expected for SWD since there was no aerosol above the FAAM BAe-146 aircraft. Lower down in the atmosphere the good agreement between model and measurements indicates that interactions between SWD and the aerosols are well represented. The best agreement for SWU is found at the lowest altitudes, which suggests that our calculated surface albedo is appropriate. Therefore, our assumptions about aerosol properties and hygroscopic growth lead to fluxes consistent with those measured when the surface albedo is also well constrained with consistent models, and we can say that radiative closure is indeed possible with our current instrumentation and a specially defined flight plan. We will use the ES96 radiative transfer model in Sect. 4 to estimate the aerosol radiative effect over Europe during other EUCAARI-LONGREX flights.

\section{Aerosol radiative effect}

The shortwave aerosol radiative effect, from now on aerosol radiative effect (ARE), is the change in net shortwave irradiance due to the presence of aerosols, $\mathrm{ARE}=\mathrm{NET}^{\text {aer }}-\mathrm{NET}^{\mathrm{clr}}$, where $\mathrm{NET}=\mathrm{SWD}-\mathrm{SWU} . \mathrm{A}$ negative value represents a decrease in the NET irradiance, likely to result in surface cooling, while a positive value suggests an increase in the NET irradiance and possible surface heating.

Having some confidence in our representation of the aged aerosol from the success of radiative closure obtained in Section 3, we would like to estimate the aerosol radiative effect at the surface and the TOA for this and other profiles from the EUCAARI-LONGREX campaign. Such a detailed validation as shown in Sect. 3 is not possible for other flights since operations and logistics did not routinely permit the specially designed flight pattern performed on flight b374. Nevertheless, the range of aerosol properties measured during EUCAARI-LONGREX can be used to drive ES96 and calculate the aerosol radiative effect for each case, albeit without radiometric validation measurements.

For each case, ES96 is provided with the in situ meteorological and aerosol measurements as described in Sect. 2.2. Additionally the surface albedo must be supplied. For flight b374 the surface albedo was obtained directly from the aircraft measurements, but this is not possible for profiles over land as air traffic restrictions prevent the aircraft from flying close to the surface. One source of surface albedo data is the MERRA reanalysis (Rienecker et al., 2011). In order to assess the sensitivity of the modelled irradiances to use of the MERRA surface albedo, the value from the MERRA reanalysis for flight b374 (0.047) has been used to rerun ES96 for this profile, and the modelled irradiances have been compared to the pyranometer measurements $(x$ symbols in Fig. 2). As we would expect, the change in surface albedo causes very small changes in the SWD irradiance $\left(<5 \mathrm{~W} \mathrm{~m}^{-2}\right)$. However, the higher surface albedo leads to an increase in the SWU irradiance such that the model overpredicts the pyranometer measurements by $8-43 \%$, this difference being now outside the uncertainty in the observations. Thus, our model calculations of SWD are more reliable than those of SWU when using the surface albedo from the MERRA reanalysis, and both SWD and SWU are less reliable than those obtained using a surface albedo from pyra- 
(a) b374 SWD

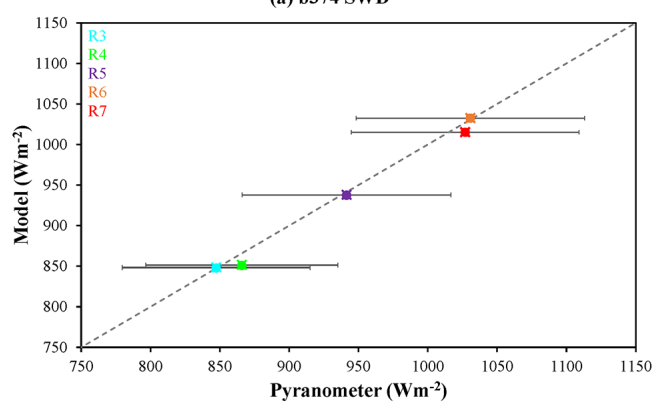

(c) b374 SWD
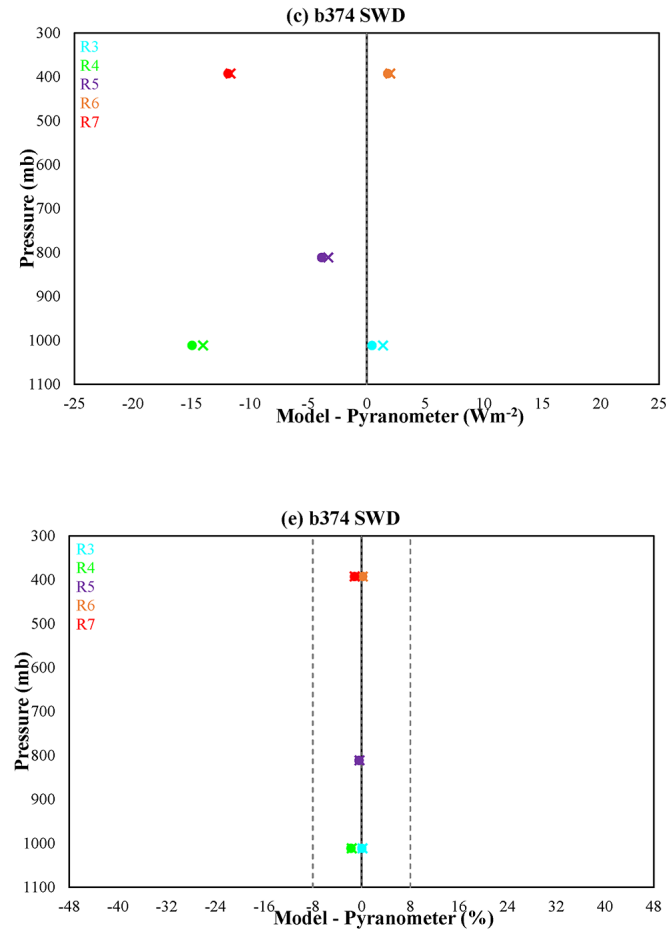

(b) b374 SWU

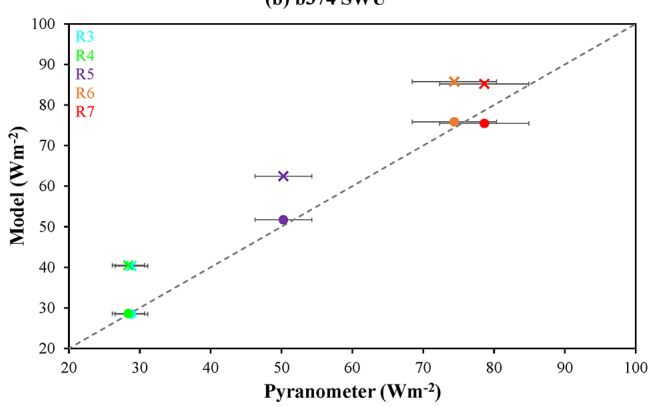

(d) b374 SWU
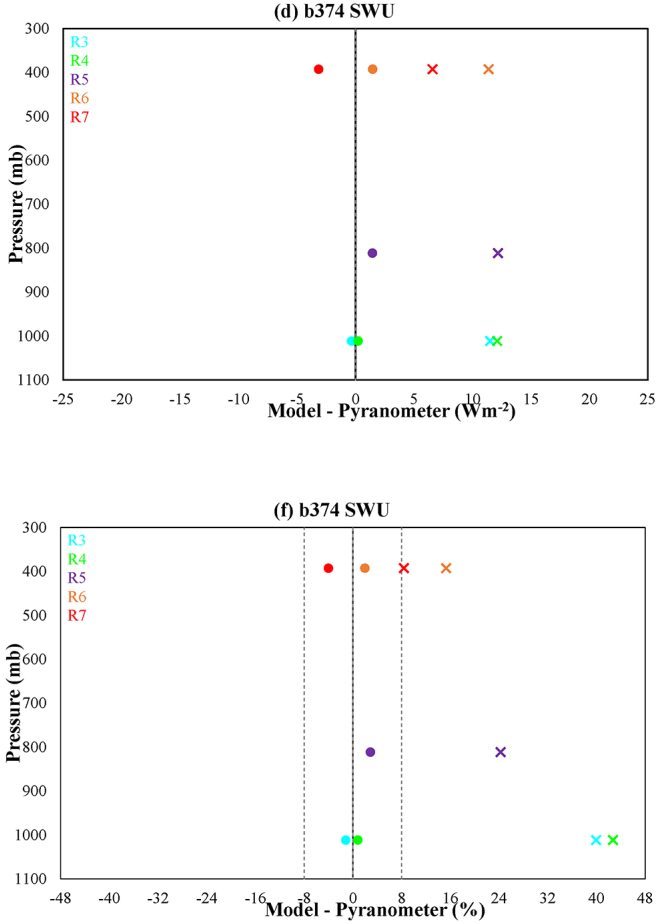

Figure 2. Comparison of modelled to measured irradiances for flight b374. (a, b) Scatter plots of modelled and measured shortwave downwelling (SWD) and upwelling (SWU) irradiances. Error bars show the maximum uncertainty of $8 \%$ in the pyranometer measurements (Haywood et al., 2001, 2003); (c, d) difference between measured and modelled irradiances as a function of the pressure at which the measurements were made; (e, f) percentage difference between measured and modelled irradiances as a function of the pressure at which the measurements were made. Dashed lines show percentage errors of less than $8 \%$, representing the maximum uncertainty in the pyranometer measurements. Dots $(\bullet)$ show results obtained with values of the surface albedo from pyranometer measurements close to the surface, and crosses $(x)$ results from the MERRA reanalysis.

nometer measurements of upwelling and downwelling irradiance during SLRs close to the surface. In Sect. 5 we will assess the sensitivity of the calculated aerosol radiative effect over Europe during EUCAARI-LONGREX to this factor.

In order to compare our results to values from the literature, the aerosol radiative effect for each flight has been diurnally averaged by calculating the irradiances at three times during each day, and weighting them based on a Gaussian distribution, which varies throughout the year. We assume that the aerosol remains unchanged diurnally.
Table 3 shows the ambient aerosol optical depth at $550 \mathrm{~nm}$ (AOD) from the aircraft profiles and dry single-scattering albedo (SSA) and specific aerosol extinction $\left(k_{\text {ext }}\right)$ at $550 \mathrm{~nm}$ from the closest SLR to each profile derived from the measurements of the aerosol scattering and absorption made by the FAAM BAe-146 aircraft, together with the diurnally averaged values of the ARE and radiative efficiency (RE) at the surface and the TOA over Europe during EUCAARILONGREX.

The highest AOD values during the EUCAARILONGREX campaign were found for flights b373 (0.176) 
Table 3. "Ambient" aerosol optical depth at $550 \mathrm{~nm}$ (AOD), "dry" single-scattering albedo at $550 \mathrm{~nm}$ (SSA), dry specific aerosol extinction at $550 \mathrm{~nm}\left(k_{\text {ext }}\right)$, and diurnally averaged values of the aerosol radiative effect (ARE) and radiative efficiency (RE) at the surface (SFC) and top of the atmosphere (TOA) across Europe during EUCAARI-LONGREX.

\begin{tabular}{llllrrrrr}
\hline Flight & Profile & AOD & SSA & $\begin{array}{r}k_{\text {ext }} \\
\left(\mathrm{m}^{2} \mathrm{~kg}^{-1}\right)\end{array}$ & $\begin{array}{r}\mathrm{ARE}_{\mathrm{SFC}} \\
\left(\mathrm{W} \mathrm{m}^{-2}\right)\end{array}$ & $\begin{array}{r}\mathrm{ARE}_{\mathrm{TOA}} \\
\left(\mathrm{W} \mathrm{m}^{-2}\right)\end{array}$ & $\begin{array}{r}\mathrm{RE}_{\mathrm{SFC}} \\
\left(\mathrm{W} \mathrm{m}^{-2} \mathrm{AOD}^{-1}\right)\end{array}$ & $\begin{array}{r}\mathrm{RE}_{\mathrm{TOA}} \\
\left(\mathrm{W} \mathrm{m}^{-2} \mathrm{AOD}^{-1}\right)\end{array}$ \\
\hline b362 & P9+P10 & 0.099 & 0.96 & 3425.9 & -7.4 & -4.4 & -75.1 & -43.9 \\
b365 & P7 & 0.047 & 0.94 & 2703.5 & -3.9 & -2.1 & -82.5 & -43.8 \\
b369 & P6.3 & 0.061 & 0.95 & 2234.3 & -8.0 & -3.0 & -131.1 & -48.7 \\
b370 & P1 & 0.101 & 0.96 & 2684.8 & -10.4 & -5.3 & -103.0 & -52.1 \\
b370 & P4.2 & 0.081 & 0.93 & 2549.7 & -9.1 & -3.7 & -112.0 & -45.4 \\
b371 & P2.2 & 0.111 & 0.95 & 1974.4 & -9.6 & -4.2 & -86.9 & -37.4 \\
b373 & P7 & 0.176 & 0.94 & 2570.6 & -15.9 & -7.6 & -90.5 & -43.1 \\
b374 & P2 & 0.126 & 0.94 & 2950.6 & -13.1 & -5.9 & -103.9 & -46.6 \\
b374 & P6 & 0.357 & 0.96 & 2628.4 & -22.8 & -12.0 & -63.9 & -33.5 \\
b380 & P3.2 & 0.099 & 0.96 & 3201.7 & -12.3 & -5.2 & -124.2 & -52.9 \\
\hline
\end{tabular}

and b374 (0.357), located on the southern UK coast and in the Atlantic Ocean south-west of Ireland, while the lowest AOD values were found for flights b365 (0.047) and b369 (0.061), performed over eastern Europe and the Baltic Sea. Considering that the majority of flights of EUCAARI-LONGREX took place during a period dominated by a strong high-surface-pressure system positioned in the region of Denmark (Morgan et al., 2010a, b; McMeeking et al., 2010; Hamburger et al., 2011), it seems that the relatively clean air mass from the Baltic Sea was swept by the anticyclonic flow south and eastwards, collecting emissions from north-western Europe, and thus the most aged aerosol sample was found to the west of Ireland. Moreover, the SSA over Europe during EUCAARILONGREX was relatively high $(>0.93)$, which reflects the large fraction of scattering material (sulphate, nitrate, and organics) in the European aerosol. The geographical and temporal variations of the aerosol scattering and absorption during EUCAARI-LONGREX have been studied in more detail by Highwood et al. (2012). Whilst any estimate of the aerosol radiative effect from a field campaign can be only a snapshot, EUCAARI-LONGREX covered more of north-western Europe than previous campaigns, and even a snapshot is useful to compare with similar snapshots from TARFOX (Russell et al., 1999), INDOEX (Ramanathan et al., 2001), the Mediterranean Intensive Oxidant Study (MINOS; Markowicz et al., 2002), ACE-Asia (Huebert et al., 2003), SAFARI 2000 (King et al., 2003), ADRIEX (Highwood et al., 2007), the Chemistry-Aerosol Mediterranean Experiment/Aerosol Direct Radiative Forcing on the Mediterranean Climate (ChArMEx/ADRIMED; Mallet et al., 2016), etc.

The diurnally averaged values of the ARE across northwestern Europe during EUCAARI-LONGREX ranged between -3.9 and $-22.8 \mathrm{~W} \mathrm{~m}^{-2}$ at the surface and from -2.1 to $-12.0 \mathrm{~W} \mathrm{~m}^{-2}$ at the TOA, with mean values for the whole campaign of $-11 \pm 5 \mathrm{~W} \mathrm{~m}^{-2}$ at the surface and
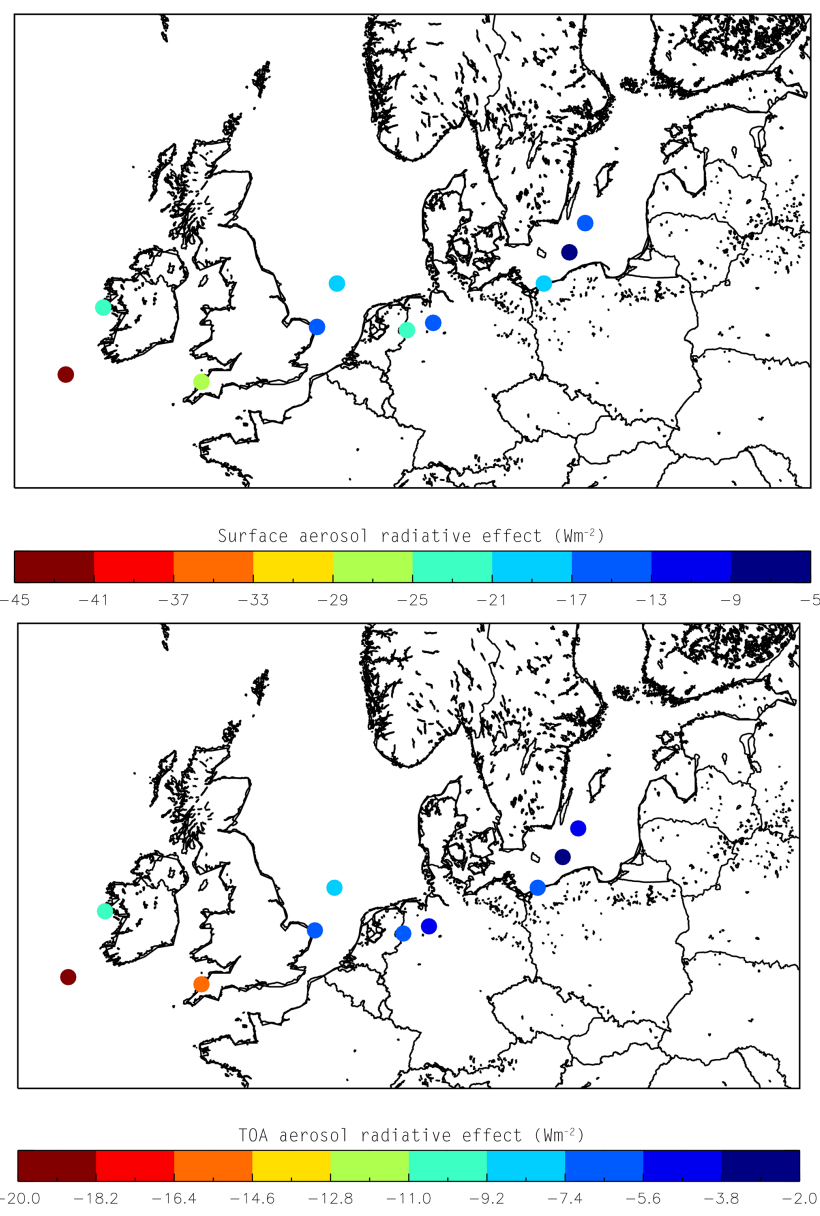

Figure 3. Aerosol radiative effect in $\mathrm{W} \mathrm{m}^{-2}$ at the surface (top) and TOA (bottom) across north-western Europe during EUCAARILONGREX. 

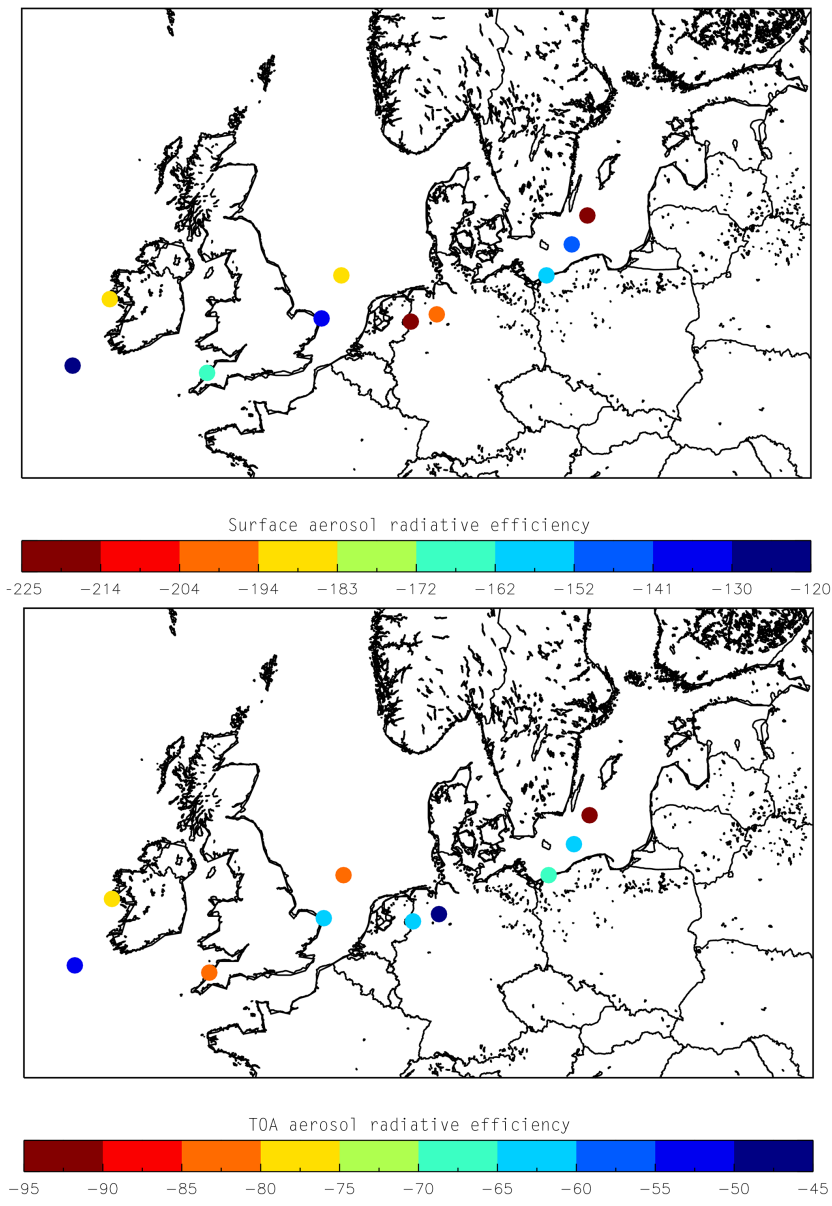

Figure 4. Aerosol radiative efficiency in $\mathrm{W} \mathrm{m}^{-2}$ per AOD unit at the surface (top) and TOA (bottom) across north-western Europe during EUCAARI-LONGREX.

$-5 \pm 3 \mathrm{~W} \mathrm{~m}^{-2}$ at the TOA. The RE (Meywerk and Ramanathan, 1999), which is independent of the solar zenith angle and the aerosol amount, has been calculated as well by normalizing the ARE values by the aerosol optical depth. The radiative efficiency during EUCAARI-LONGREX ranged between -63.9 and $-131.1 \mathrm{~W} \mathrm{~m}^{-2}$ per AOD unit at the surface and from -33.5 to $-52.9 \mathrm{~W} \mathrm{~m}^{-2}$ per AOD unit at the TOA, with mean values for the whole campaign of $-97 \pm 21$ and $-45 \pm 6 \mathrm{~W} \mathrm{~m}^{-2}$ per AOD unit at the surface and the TOA, respectively. Figures 3 and 4 show these diurnally averaged values of the aerosol radiative effect and radiative efficiency across north-western Europe during EUCAARILONGREX. It is observed that the largest aerosol radiative effect was obtained to the west of Ireland, where the largest AOD and the most aged aerosol sample were found, while the smallest was obtained over the Baltic Sea, where the lowest AOD and the cleanest air mass were found.

The results obtained for the aerosol radiative effect over Europe during EUCAARI-LONGREX are similar to those reported in one of the most polluted regions in Europe, the
Po Valley in northern Italy, where the mean daily aerosol forcing ranged between $-10 \pm 5$ and $-14 \pm 7 \mathrm{~W} \mathrm{~m}^{-2}$ at the surface and between $-4 \pm 2$ and $-8 \pm 4 \mathrm{~W} \mathrm{~m}^{-2}$ at the TOA during ADRIEX (Barnaba et al., 2007). The uncertainty in our results falls also within the reported values for MINOS, where the mean daily aerosol forcing was $-8 \pm 2 \mathrm{~W} \mathrm{~m}^{-2}$ at the surface and $-6 \pm 2 \mathrm{~W} \mathrm{~m}^{-2}$ at the TOA (Markowicz et al., 2002). However, the aerosol radiative effect obtained over Europe during EUCAARI-LONGREX is smaller than that obtained on the eastern coast of the United States in one of the world's major industrial pollution plumes (ARE $=-26$ at the surface and $-9 \mathrm{~W} \mathrm{~m}^{-2}$ at the TOA) (Hignett et al., 1999), with the exception of the more polluted and aged aerosol case of flight b374. Thus the aerosol radiative effect calculated from the EUCAARI-LONGREX measurements contributes to a bank of measurements showing that - under aged, relatively polluted conditions - radiative effects across Europe can be sizeable.

\section{Sensitivity of calculated aerosol radiative effect}

The values of the aerosol radiative effect calculated in Sect. 4 include uncertainties due to the modelling methods used in the radiative transfer model and the spatial variations in the aerosol. There are a number of assumptions made in calculating the aerosol radiative effect, and we test the relative importance of these in this section. Figure 5 shows in a box-andwhisker diagram the sensitivity (in percentage) of the calculated aerosol radiative effect at the surface and the TOA to the various assumptions or choices made in the radiative transfer modelling, these being spectral resolution of the information used in ES96 (SP_RES), the aerosol description (composition and size distribution) used in the Mie calculations of the aerosol optical properties included in the radiative transfer model (AVG_AER), the surface albedo (SFC_ALB), the SSA and the hygroscopicity of organic aerosol (GF_OC). The number of cases with an increase $(\uparrow)$ or decrease $(\downarrow)$ of the calculated aerosol radiative effect is also shown. The sensitivity to the various assumptions made in the radiative transfer model is estimated by repeating our calculations of the aerosol radiative effect using a different assumption and then comparing the new results with the original values and calculating the difference between them. All the flights and deep vertical profiles made during EUCAARILONGREX that have been used to calculate the radiative effect of aerosols over Europe have been used in these tests.

\subsection{Sensitivity to modelling methods}

The ES96 model covers the range $0.2-10 \mu \mathrm{m}$, but its spectral resolution is flexible, with differing resolutions typically being used for offline calculations ( 220 bands, as in the previous sections of this paper) and within numerical weather prediction (NWP) and climate models (more typically 6 bands). 
(a) Surface

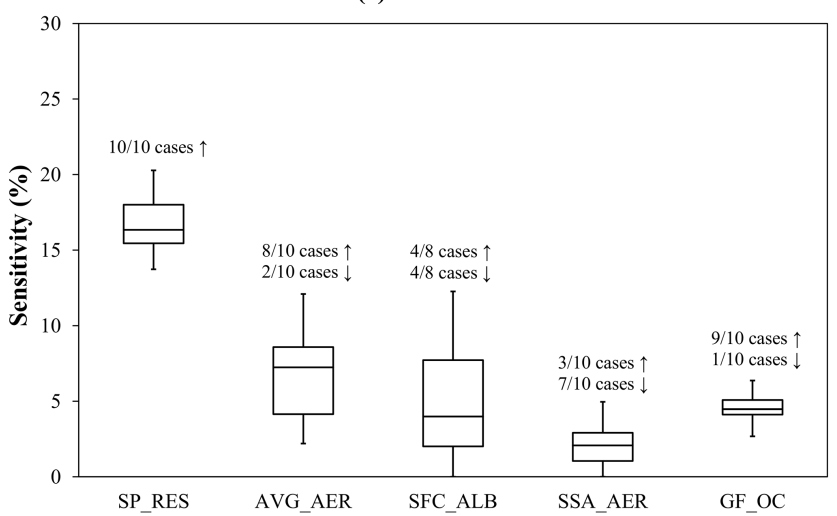

(b) TOA

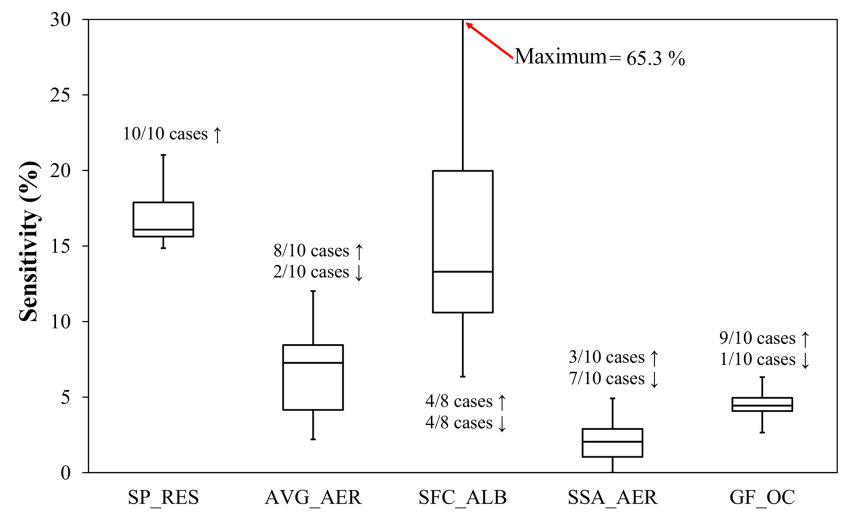

Figure 5. Sensitivity (in percentage) of the calculated aerosol radiative effect at the (a) surface and (b) TOA to the spectral resolution of the information used in the ES96 radiative transfer model (SP_RES), the aerosol description (AVG_AER), the surface albedo (SFC_ALB), the single-scattering albedo (SSA), and the hygroscopicity of organic aerosol (GF_OC). The dividing segment in the box is the median. The bottom and top box limits represent the 1 st and 3rd quartiles, respectively. The box bars represent the minimum and maximum. The number of cases with an increase $(\uparrow)$ or decrease $(\downarrow)$ of the calculated aerosol radiative effect is also shown.

Figure S1 in the Supplement shows the spectral dependence of the aerosol extinction, the single-scattering albedo, and the phase function over the ranges $0.2-10 \mu \mathrm{m}$. To test the sensitivity of the calculated aerosol radiative effect to the spectral resolution of the information used in ES96, we have repeated our calculations using the spectral resolution used for the HadGEM climate model and the Met Office global forecast model. The changes in the calculated ARE (SP_RES in Fig. 5) compared to our original higher-spectral-resolution version are large: an increase of $\sim 17 \%$ on average and up to $20-21 \%$ at the surface and the TOA.

The sensitivity to the surface albedo is tested here by repeating our calculations of the aerosol radiative effect with values of the surface albedo from pyranometer measurements of upwelling and downwelling irradiance during SLRs close to the surface whenever it was possible, instead of using values from the MERRA reanalysis. The change in the calculated ARE (SFC_ALB in Fig. 5) is either an increase or a decrease, and at the surface it is relatively low: $6 \%$ on average and up to $12 \%$. However, the calculated ARE at the TOA is much more sensitive to the surface albedo: $\sim 20 \%$ on average and up to $\sim 65 \%$.

Esteve et al. (2014) found that one of the largest sources of uncertainty in the calculated scattering is the assumed hygroscopic growth factor for organic aerosol. To test the sensitivity of the calculated aerosol radiative effect to the hygroscopic growth factor for organic aerosol used in the Mie calculations of the aerosol optical properties included in ES96, we have repeated our calculations using the value from Gysel et al. (2007), which is independent of the ambient relative humidity, instead of the hygroscopic growth factor from Brooks et al. (2004). The change in the calculated ARE is similar at the surface and TOA (GF_OC in Fig. 5): an increase of $\sim 5 \%$.

\subsection{Sensitivity to spatial variations in aerosol}

Aerosol optical properties are included in the ES96 radiative transfer model by calculating them with a Mie scattering code based on their composition and size distribution (Esteve et al., 2014). To test the relative importance of representing the spatial variability of aerosol optical properties, we have repeated our calculations using flight-mean aerosol compositions and size distributions instead of the measured ones for the closest SLRs to each vertical profile of EUCAARILONGREX used here. The change in the calculated ARE for a particular SLR when using local vs. flight-mean values (AVG_AER in Fig. 5) is an increase of $\sim 7 \%$ on average and up to $12 \%$ at the surface and the TOA, which agrees with the change in the calculated aerosol optical properties of $\sim 7 \%$ on average and up to $14 \%$.

The ES96 radiative transfer model requires the vertical aerosol profile in terms of mass mixing ratio as an input. This is derived from the measured scattering profile, but this calculation requires inputs of SSA and mass extinction coefficient. To test the sensitivity of the calculated aerosol radiative effect to the single-scattering albedo used in this conversion, we have repeated our calculations using flight-mean values of the SSA instead of those matching the closest SLRs to each vertical profile of EUCAARI-LONGREX (resulting in SSA differences of $2.6 \%$ on average and up to $11 \%$ ). (Note that the optical properties of aerosol applied in the radiative transfer calculations are not changed here; only the column mass of aerosol is changed.) The change in the calculated ARE (SSA_AER in Fig. 5) is a decrease of $~ 2 \%$ on average and up to $5 \%$ at the surface and the TOA. The change in the SSA is buffered by other factors in the model. 


\section{Conclusions}

The still rather uncertain radiative effect of anthropogenic aerosols during an anticyclonic episode over north-western Europe during the EUCAARI-LONGREX campaign has been calculated using the data collected by the FAAM BAe146 aircraft. As well as adding a valuable north-western Europe case to the growing inventory of aerosol property and radiative effect case studies over Europe, we have systematically quantified the uncertainties in our calculations due to the variations in the aerosol optical properties across Europe and the way in which they are represented in a radiative transfer model.

Pyranometer measurements aboard the FAAM BAe-146 aircraft were first used together with modelled irradiances in a case of aged European aerosol during one flight to validate the results from the model and evaluate the degree of radiative closure that can be achieved when flight patterns and atmospheric conditions are both optimal. The agreement between model and measurements for both the shortwave downwelling and upwelling irradiances was within the pyranometer uncertainty, suggesting that our model calculations of the aerosol radiative effect are as reliable as is possible with current instrumentation so long as the flight plan is designed for this purpose.

For the rest of the EUCAARI-LONGREX flights, full radiative closure flight patterns could not be performed due to operational aircraft logistics. Nevertheless, for these flights the aerosol radiative effect during EUCAARI-LONGREX was calculated and found to increase from north-east to south-west across Europe, in conjunction with the aging and transport of the polluted air mass, ranging between -3.9 and $-22.8 \mathrm{~W} \mathrm{~m}^{-2}$ at the surface and from -2.1 to $-12.0 \mathrm{~W} \mathrm{~m}^{-2}$ at the TOA. The largest aerosol radiative effect was obtained to the west of Ireland, where the largest AOD of 0.357 and the most aged aerosol sample was found. The mean aerosol radiative effect for the whole campaign was $-11 \pm 5 \mathrm{~W} \mathrm{~m}^{-2}$ at the surface and $-5 \pm 3 \mathrm{~W} \mathrm{~m}^{-2}$ at the TOA. The mean radiative efficiency during EUCAARILONGREX was $-97 \pm 21$ and $-45 \pm 6 \mathrm{~W} \mathrm{~m}^{-2}$ per AOD unit at the surface and the TOA, respectively.

We also quantified here the uncertainties in our calculations due to the modelling methods used in the radiative transfer model and the spatial variations in the aerosol. The largest uncertainty in the aerosol radiative effect at the surface and the TOA came from the spectral resolution used in the radiative transfer model $(\sim 17 \%$ on average and up to $\sim 20-21 \%$ ) and the aerosol description, i.e., measured aerosol composition and size distribution for the closest SLRs to each vertical profile vs. flight-mean values $(\sim 7 \%$ on average and up to $\sim 12 \%$ ). The aerosol radiative effect at the TOA was found to be also highly sensitive to the surface albedo $(\sim 12 \%$ on average and up to $\sim 65 \%)$. The sensitivity of the aerosol radiative effect to the single-scattering albedo used to estimate the column mass of aerosol (with- out changing the aerosol optical properties) and to the hygroscopic growth factor for organic aerosol used in the Mie calculations of the aerosol optical properties included in ES96 was found to be relatively low: $\sim 2$ and $\sim 5 \%$ on average, respectively.

These results suggest that spatial variation of aerosol optical properties influences radiative effect estimates even in an area of generally high aerosol load. This poses a challenge for models to capture the variability in aerosol optical properties and their changes during the aging process, in order to represent the radiative effect of aerosols to around a $10 \%$ uncertainty level. Of even greater importance is a good representation of surface albedo - introducing an uncertainty of between 12 and $65 \%$ in the TOA aerosol radiative effect. Airborne field experiments and comparison with radiative transfer models can provide guidance in this way as to where to concentrate improvements in NWP and climate models.

\section{Data availability}

The FAAM data are publicly available at http://catalogue. ceda.ac.uk/uuid/7e76016a24f7435da11b026d966ec4bf (Facility for Airborne Atmospheric Measurements; Met Office; Natural Environment Research Council, NERC, 2016). The MERRA data are publicly available at http://disc.sci. gsfc.nasa.gov/uui/datasets/MAT1NXRAD_V5.2.0/summary (Global Modeling and Assimilation Office, 2008).

\section{The Supplement related to this article is available online at doi:10.5194/acp-16-7639-2016-supplement.}

Acknowledgements. This work was supported by NERC ADIENT project NE/E011101/1 and EUCAARI project 036833-2. The collaboration of Anna R. Esteve was possible thanks to the VALi+d postdoctoral fellowship APOSTD/2012/078 of the Valencian Autonomous Government and the project CGL2012-33294 of the Spanish Ministry of Economy and Competitiveness and the European Regional Development Fund. We thank the Facility for Airborne Atmospheric Measurements (FAAM), the Met Office, and DirectFlight Ltd. staff for their contributions to the campaign.

Edited by: Y. Balkanski 


\section{References}

Anderson, T. L. and Ogren, J. A.: Determining aerosol radiative properties using the TSI 3563 integrating nephelometer, Aerosol Sci. Tech., 29, 57-69, doi:10.1080/02786829808965551, 1999.

Barnaba, F., Gobbi, G. P., and de Leeuw, G.: Aerosol stratification, optical properties and radiative forcing in Venice (Italy) during ADRIEX, Q. J. Roy. Meteor. Soc, 133, 47-60, doi:10.1002/qj.91, 2007.

Bond, T. C. and Bergstrom, R. W.: Light absorption by carbonaceous particles: an investigative review, Aerosol Sci. Tech., 40, 27-67, doi:10.1080/02786820500421521, 2006.

Bond, T. C., Anderson, T. L, and Campbell, D.: Calibration and intercomparison of fliter-based measurements of visible light absorption by aerosols, Aerosol Sci. Tech., 30, 582-600, doi:10.1080/027868299304435, 1999.

Brooks, S. D., DeMott, P. J., and Kreidenweis, S. M.: Water uptake by particles containing humic materials and mixtures of humic materials with ammonium sulfate, Atmos. Environ., 38, 18591868, doi:10.1016/j.atmosenv.2004.01.009, 2004.

Burns, S. P., Khelif, D., Friehe, C. A., Hignett, P., Williams, A. G., Grant, A. L. M., Hacker, J. M., Hagan, D. E., Serra, Y. L., Rogers, D. P., Bradley, E. F., Weller, R. A., Fairall, C. W., Anderson, S. P., Paulson, C. A., and Coppin, P. A.: Comparisons of aircraft, ship, and buoy radiation and SST measurements from TOGA COARE, J. Geophys. Res., 105, 1562715652, doi:10.1029/2000JD900090, 2000.

Canagaratna, M. R., Jayne, J. T., Jimenez, J. L., Allan, J. D., Alfarra, M. R., Zhang, Q., Onasch, T. B., Drewnick, F., Coe, H., Middlebrook, A., Delia, A., Williams, L. R., Trimborn, A. M., Northway, M. J., DeCarlo, P. F., Colb, C. E., Davidovits, P., and Worsnop, D. R.: Chemical and microphysical characterization of ambient aerosols with the aerodyne aerosol mass spectrometer, Mass Spectrom. Rev., 26, 185-222, doi:10.1002/mas.20115, 2007.

Charlson, R. J., Schwartz, S. E., Hales, J. M., Cess, R. D., Coakley Jr., J. A., Hansen, J. E., and Hofmann, D. J.: Climate forcing by anthropogenic aerosols, Science, 255, 423-430, doi:10.1126/science.255.5043.423, 1992.

Diner, D. J., Ackerman, T. P., Anderson, T. L., Bösenberg, J., Braverman, A. J., Charlson, R. J., Collins, W. D., Davies, R., Holben, B. N., Hostetler, C. A., Kahn, R. A., Martonchik, J. V., Menzies, R. T., Miller, M. A., Ogren, J. A., Penner, J. E., Rasch, P. J., Schwartz, S. E., Seinfeld, J. H., Stephens, G. L., Torres, O., Travis, L. D., Wielicki, B. A., and Yu, B.: Progressive Aerosol Retrieval and Assimilation Global Observing Network (PARAGON): An integrated approach for characterizing aerosol climatic and environmental interactions, B. Am. Meteorol. Soc., 85, 1491-1501, doi:10.1175/BAMS-85-10-1491, 2004.

Edwards, J. M. and Slingo, A.: Studies with a flexible new radiation code. I: Choosing a configuration for a large-scale model, Q. J. Roy. Meteor. Soc., 122, 689-719, doi:10.1002/qj.49712253107, 1996.

Esteve, A. R., Highwood, E. J., Morgan, W. T., Allen, G., Coe, H., Grainger, R. G., Brown, P., and Szpek, K.: A study on the sensitivities of simulated aerosol optical properties to composition and size distribution using airborne measurements, Atmos. Environ., 89, 517-524, doi:10.1016/j.atmosenv.2014.02.063, 2014.

Facility for Airborne Atmospheric Measurements; Met Office; Natural Environment Research Council (NERC): EUCAARI: in-situ airborne observations by the FAAM BAE-146 aircraft. NCAS British Atmospheric Data Centre, available at: http://catalogue. ceda.ac.uk/uuid/7e76016a24f7435da11b026d966ec4bf, last access: 21 June 2016.

Global Modeling and Assimilation Office (GMAO): tavg1_2d_rad_Nx: MERRA 2D IAU Diagnostic, Radiation Surface and TOA, Time Average 1-hourly, version 5.2.0, Greenbelt, MD, USA, Goddard Earth Sciences Data and Information Services Center (GES DISC), available at: doi:10.5067/RI9VTUQN74XJ (last access: 21 June 2016), 2008.

Gysel, M., Crosier, J., Topping, D. O., Whitehead, J. D., Bower, K. N., Cubison, M. J., Williams, P. I., Flynn, M. J., McFiggans, G. B., and Coe, H.: Closure study between chemical composition and hygroscopic growth of aerosol particles during TORCH2, Atmos. Chem. Phys., 7, 6131-6144, doi:10.5194/acp-7-61312007, 2007.

Hamburger, T., McMeeking, G., Minikin, A., Birmili, W., Dall'Osto, M., O’Dowd, C., Flentje, H., Henzing, B., Junninen, H., Kristensson, A., de Leeuw, G., Stohl, A., Burkhart, J. F., Coe, H., Krejci, R., and Petzold, A.: Overview of the synoptic and pollution situation over Europe during the EUCAARILONGREX field campaign, Atmos. Chem. Phys., 11, 10651082, doi:10.5194/acp-11-1065-2011, 2011.

Haywood, J., Francis, P., Glew, M., and Taylor, J.: Optical properties and direct radiative effect of Saharan dust: a case study of two Saharan dust outbreaks using aircraft data, J. Geophys. Res., 106, 18417-18430, doi:10.1029/2000JD900319, 2001.

Haywood, J., Francis, P., Osborne, S., Glew, M., Loeb, N., Highwood, E., Tanré, D., Mhyre, G., Formenti, P., and Hirst, E.: Radiative properties and direct radiative effect of Saharan dust measured by the C-130 aircraft during SHADE: 1 . Solar spectrum, J. Geophys. Res., 108, 8577, doi:10.1029/2002JD002687, 2003.

Haywood, J. M. and Shine, K. P.: Multi-spectral calculations of the direct radiative forcing of tropospheric sulphate and soot aerosols using a column model, Q. J. Roy. Meteor. Soc., 123, 1907-1930, doi:10.1002/qj.49712354307, 1997.

Haywood, J. M., Bush, M., Abel, S., Claxton, B., Coe, H., Crosier, J., Harrison, M., MacPherson, B., Naylor, M., and Osborne, S.: Prediction of visibility and aerosol within the operational Met Office Unified Model. II. Validation of model performance using observational data, Q. J. Roy. Meteor. Soc., 134, 1817-1832, doi:10.1002/qj.275, 2008.

Heintzenberg, J., Graf, H.-F., Charlson, R. J., and Warneck, P.: Climate forcing and the physico-chemical life cycle of the atmospheric aerosol - Why do we need an integrated, interdisciplinary global research programme?, Contrib. Atmos. Phys., 69, 261272, 1996.

Highwood, E. J., Haywood, J. M., Coe, H., Cook, J., Osborne, S., Williams, P., Crosier, J., Formenti, P., McQuaid, J., Brooks, B., Thomas, G., Grainger, R., Barnaba, F., Gobbi, G. P., and De Leeuw, G.: Aerosol Direct Radiative Impact Experiment (ADRIEX) overview, Q. J. Roy. Meteor. Soc., 133, 3-15, doi:10.1002/qj.89, 2007.

Highwood, E. J., Northway, M. J., McMeeking, G. R., Morgan, W. T., Liu, D., Osborne, S., Bower, K., Coe, H., Ryder, C., and Williams, P.: Aerosol scattering and absorption during the EUCAARI-LONGREX flights of the Facility for Airborne Atmospheric Measurements (FAAM) BAe-146: can measure- 
ments and models agree?, Atmos. Chem. Phys., 12, 7251-7267, doi:10.5194/acp-12-7251-2012, 2012.

Hignett, P., Taylor, J. P., Francis, P. N., and Glew, M. D.: Comparison of observed and modeled direct aerosol forcing during TARFOX, J. Geophys. Res., 104, 2279-2287, doi:10.1029/98JD02021, 1999.

Huebert, B. J., Bates, T., Russell, P. B., Shi, G., Kim, Y. J., Kawamura, K., Carmichael, G., and Nakajima, T.: An overview of ACE-Asia: Strategies for quantifying the relationships between Asian aerosols and their climatic impacts, J. Geophys. Res., 108, 8633, doi:10.1029/2003JD003550, 2003.

IPCC: Climate Change 2013: The Physical Science Basis. Contribution of Working Group I to the Fifth Assessment Report of the Intergovernmental Panel on Climate Change, edited by: Stocker, T. F., Qin, D., Plattner, G.-K., Tignor, M., Allen, S. K., Boschung, J., Nauels, A., Xia, Y., Bex, V., and Midgley, P. M., Cambridge University Press, Cambridge, UK and New York, NY, USA, 2013.

Jin, Z., Charlock, T. P., Smith Jr., W. L., and Rutledge, K.: A parameterization of ocean surface albedo, Geophys. Res. Lett., 31, L22301, doi:10.1029/2004GL021180, 2004.

Johnson, B. J. and Osborne, S. R.: Physical and optical properties of mineral dust aerosol measured by aircraft during the GERBILS campaign, Q. J. Roy. Meteor. Soc., 137, 1117-1130, doi:10.1002/qj.777, 2011.

Johnson, D. W., Osborne, S. R., Wood, R., Suhre, K., Johnson, R., Businger, S., Quinn, P. K., Wiedensohler, A., Durkee, P. A., Russell, L. M., Andreae, M., O’Dowd, C., Noone, K., Namdy, B., Rudolph, J., and Rapsomanikas, S.: An overview of the Lagrangian experiments undertaken during the North Atlantic Aerosol Characterisation experiments (ACE-2), Tellus B, 52, 290-320, doi:10.1034/j.1600-0889.2000.00057.x, 2000.

Kahn, R., Ogren, J. A., Ackerman, T. P., Bösenberg, J., Charlson, R. J., Diner, D. J., Holben, B. N., Menzies, R. T., Miller, M. A., and Seinfeld, J. H.: Aerosol data sources and their roles within PARAGON, B. Am. Meteorol. Soc., 85, 1511-1522, doi:10.1175/BAMS-85-10-1511, 2004.

Kaufman, Y. J., Koren, I., Remer, L. A., Rosenfeld, D., and Rudich, Y.: The effect of smoke, dust, and pollution aerosol on shallow cloud development over the Atlantic Ocean, P. Natl. Acad. Sci. USA, 102, 11207-11212, doi:10.1073/pnas.0505191102, 2005.

King, M. D., Platnick, S., Moeller, C. C., Revercomb, H. E., and Chu, D. A.: Remote sensing of smoke, land, and clouds from the NASA ER-2 during SAFARI 2000, J. Geophys. Res., 108, 8502, doi:10.1029/2002JD003207, 2003.

Mallet, M., Dulac, F., Formenti, P., Nabat, P., Sciare, J., Roberts, G., Pelon, J., Ancellet, G., Tanré, D., Parol, F., Denjean, C., Brogniez, G., di Sarra, A., Alados-Arboledas, L., Arndt, J., Auriol, F., Blarel, L., Bourrianne, T., Chazette, P., Chevaillier, S., Claeys, M., D’Anna, B., Derimian, Y., Desboeufs, K., Di Iorio, T., Doussin, J.-F., Durand, P., Féron, A., Freney, E., Gaimoz, C., Goloub, P., Gómez-Amo, J. L., Granados-Muñoz, M. J., Grand, N., Hamonou, E., Jankowiak, I., Jeannot, M., Léon, J.-F., Maillé, M., Mailler, S., Meloni, D., Menut, L., Momboisse, G., Nicolas, J., Podvin, T., Pont, V., Rea, G., Renard, J.-B., Roblou, L., Schepanski, K., Schwarzenboeck, A., Sellegri, K., Sicard, M., Solmon, F., Somot, S., Torres, B., Totems, J., Triquet, S., Verdier, N., Verwaerde, C., Waquet, F., Wenger, J., and Zapf, P.: Overview of the Chemistry-Aerosol Mediterranean Exper-
iment/Aerosol Direct Radiative Forcing on the Mediterranean Climate (ChArMEx/ADRIMED) summer 2013 campaign, Atmos. Chem. Phys., 16, 455-504, doi:10.5194/acp-16-455-2016, 2016.

Markowicz, K. M., Flatau, P. J., Ramana, M. V., Crutzen, P. J., and Ramanathan, V.: Absorbing mediterranean aerosols lead to a large reduction in the solar radiation at the surface, Geophys. Res. Lett., 29, 1968, doi:10.1029/2002GL015767, 2002.

McClatchey, R., Fenn, R., Selby, J., Volz, F., and Garing, J.: Optical properties of the atmosphere, ARCRL-71-0279, Air Force Geophysics Lab, Bedford, MA, USA, 1971.

McMeeking, G. R., Hamburger, T., Liu, D., Flynn, M., Morgan, W. T., Northway, M., Highwood, E. J., Krejci, R., Allan, J. D., Minikin, A., and Coe, H.: Black carbon measurements in the boundary layer over western and northern Europe, Atmos. Chem. Phys., 10, 9393-9414, doi:10.5194/acp-10-9393-2010, 2010.

Meywerk, J. and Ramanathan, V.: Observations of the spectral clear-sky aerosol forcing over the tropical Indian Ocean, J. Geophys. Res., 104, 24359-24370, doi:10.1029/1999JD900502, 1999.

Morgan, W. T., Allan, J. D., Bower, K. N., Highwood, E. J., Liu, D., McMeeking, G. R., Northway, M. J., Williams, P. I., Krejci, R., and Coe, H.: Airborne measurements of the spatial distribution of aerosol chemical composition across Europe and evolution of the organic fraction, Atmos. Chem. Phys., 10, 4065-4083, doi:10.5194/acp-10-4065-2010, 2010a.

Morgan, W. T., Allan, J. D., Bower, K. N., Esselborn, M., Harris, B., Henzing, J. S., Highwood, E. J., Kiendler-Scharr, A., McMeeking, G. R., Mensah, A. A., Northway, M. J., Osborne, S., Williams, P. I., Krejci, R., and Coe, H.: Enhancement of the aerosol direct radiative effect by semi-volatile aerosol components: airborne measurements in North-Western Europe, Atmos. Chem. Phys., 10, 8151-8171, doi:10.5194/acp-10-81512010, $2010 b$.

Ogren, J. A.: Comment on "Calibrations and Intercomparison of fliter-based measurements of Visible Light Absorption by Aerosols", Aerosol Sci. Tech., 44, 589-591, doi:10.1080/02786826.2010.482111, 2010.

Osborne, S. R., Haywood, J. M., and Bellouin, N.: In situ and remote-sensing measurements of the mean microphysical and optical properties of industrial pollution aerosol during ADRIEX, Q. J. Roy. Meteor. Soc., 133, 17-32, doi:10.1002/qj.92, 2007.

Penner, J. E., Charlson, R. J., Hales, J. M., Laulainen, N. S., Travis, L., Leifer, R., Novakov, T., Ogren, J., and Radke, L. F.: Quantifying and minimizing uncertainty of climate forcing by anthropogenic aerosols, B. Am. Meteorol. Soc., 75, 375-400, doi:10.1175/1520-0477(1994)075<0375:QAMUOC>2.0.CO;2, 1994.

Ramanathan, V., Crutzen, P. J., Lelieveld, J., Mitra, A. P., Althausen, D., Anderson, J., Andreae, M. O., Cantrell, W., Cass, G. R., Chung, C. E., Clarke, A. D., Coakley, J. A., Collins, W. D., Conant, W. C., Dulac, F., Heintzenberg, J., Heymsfield, A. J., Holben, B., Howell, S., Hudson, J., Jayaraman, A., Kiehl, J. T., Krishnamurti, T. N., Lubin, D., McFarquhar, G., Novakov, T., Ogren, J. A., Podgorny, I. A., Prather, K., Priestley, K., Prospero, J. M., Quinn, P. K., Rajeev, K., Rasch, P., Rupert, S., Sadourny, R., Satheesh, S. K., Shaw, G. E., Sheridan, P., and Valero, F. P. J.: Indian Ocean Experiment: An integrated analysis of the climate 
forcing and effects of the great Indo-Asian haze, J. Geophys. Res., 106, 28371-28398, doi:10.1029/2001JD900133, 2001.

Randles, C. A., Kinne, S., Myhre, G., Schulz, M., Stier, P., Fischer, J., Doppler, L., Highwood, E., Ryder, C., Harris, B., Huttunen, J., Ma, Y., Pinker, R. T., Mayer, B., Neubauer, D., Hitzenberger, R., Oreopoulos, L., Lee, D., Pitari, G., Di Genova, G., Quaas, J., Rose, F. G., Kato, S., Rumbold, S. T., Vardavas, I., Hatzianastassiou, N., Matsoukas, C., Yu, H., Zhang, F., Zhang, H., and $\mathrm{Lu}$, P.: Intercomparison of shortwave radiative transfer schemes in global aerosol modeling: results from the AeroCom Radiative Transfer Experiment, Atmos. Chem. Phys., 13, 2347-2379, doi:10.5194/acp-13-2347-2013, 2013.

Rienecker, M. M., Suarez, M. J., Gelaro, R., Todling, R., Bacmeister, J., Liu, E., Bosilovich, M. G., Schubert, S. D., Takacs, L., Kim, G.-K., Bloom, S., Chen, J., Collins, D., Conaty, A., da Silva, A., Gu, W., Joiner, J., Koster, R. D., Lucchesi, R., Molod, A., Owens, T., Pawson, S., Pegion, P., Redder, C. R., Reichle, R., Robertson, F. R., Ruddick, A. G., Sienkiewicz, M., and Woollen, J.: MERRA: NASA's Modern-Era Retrospective Analysis for Research and Applications, J. Climate, 24, 3624-3648, doi:10.1175/JCLI-D-11-00015.1, 2011.

Rosenberg, P. D., Dean, A. R., Williams, P. I., Dorsey, J. R., Minikin, A., Pickering, M. A., and Petzold, A.: Particle sizing calibration with refractive index correction for light scattering optical particle counters and impacts upon PCASP and CDP data collected during the Fennec campaign, Atmos. Meas. Tech., 5, 1147-1163, doi:10.5194/amt-5-1147-2012, 2012.

Russell, P. B., Livingston, J. M., Hignett, P., Kinne, S., Wong, J., Chien, A., Bergstrom, R., Durkee, P., and Hobbs, P. V.: Aerosol induced radiative flux changes off the United States mid-Atlantic coast: comparison of values calculated from sun photometer and in situ data with those measured by airborne pyranometer, J. Geophys. Res., 104, 2289-2307, doi:10.1029/1998JD200025, 1999.
Schwarz, J. P., Gao, R. S., Fahey, D. W., Thomson, D. S., Watts, L. A., Wilson, J. C., Reeves, J. M., Darbeheshti, M., Baumgardner, D. G., Kok, G. L., Chung, S. H., Schulz., M., Hendriks, J., Lauer, A., Karcher, B., Slowik, J. G., Rosenlof, K. H., Thompson, T. L., Langford, A. O., Lowenstein, M., and Aiken, K. C.: Single particle measurements of mid-latitude black carbon and light-scattering aerosols from the boundary layer to the lower stratosphere, J. Geophys. Res., 110, D16207, doi:10.1029/2006JD007076, 2006.

Strapp, J. W., Leaitch, W. R., and Liu, P. S. K.: Hydrated and Dried Aerosol-Size-Distribution Measurements from the Particle Measuring Systems FSSP-300 Probe and the Deiced PCASP-100X Probe, J. Atmos. Oceanic Tech., 9, 548-555, doi:10.1175/15200426(1992)009<0548:HADASD>2.0.CO;2, 1992.

Turnbull, K.: PSAP Corrections: Amendment to MRF Technical Note No. 31, OBR Technical Note, No. 80, Met Office, available at: http://www.faam.ac.uk/index.php/faam-documents/ science-instruments/1553-psap-obr-tn80-v1-0/file (last access: 21 June 2016), 2010.

Yu, H., Kaufman, Y. J., Chin, M., Feingold, G., Remer, L. A., Anderson, T. L., Balkanski, Y., Bellouin, N., Boucher, O., Christopher, S., DeCola, P., Kahn, R., Koch, D., Loeb, N., Reddy, M. S., Schulz, M., Takemura, T., and Zhou, M.: A review of measurement-based assessments of the aerosol direct radiative effect and forcing, Atmos. Chem. Phys., 6, 613-666, doi:10.5194/acp-6-613-2006, 2006. 